\title{
HUMAN CHROMOSOMAL HETEROMORPHISMS IN AMERICAN BLACKS VII. CORRELATION (r) BETWEEN HEIGHT AND THE SIZE OF THE Y CHROMOSOME
}

\author{
Ram S. VERMA ${ }^{1}$ and Harvey Dosik ${ }^{2}$ \\ ${ }^{1}$ Divisions of Cytogenetics and Hematology, The Jewish Hospital \\ and Medical Center of Brooklyn, N.Y. 11238, U.S.A. \\ ${ }^{2}$ Department of Medicine, State University of New York, \\ Downstate Medical Center, Brooklyn, N.Y. 11238, U.S.A.
}

\begin{abstract}
Summary Fifty normal American Blacks were selected to examine the correlation between the length of the $\mathrm{Y}$ chromosome and their height using QFQ technique. Chromosomes 19 and 20 (F group) and $\mathrm{Y}$ were measured directly from the film and $\mathrm{Y} / \mathrm{F}$ indices were calculated as a parameter of $\mathrm{Y}$ length. The average length of the $Y$ chromosome was 1.09. There was no correlation between the height of an individual with the length of his $\mathrm{Y}$ $(p>.01)$. The biological and clinical significance of human $Y$ chromosome heteromorphisms is discussed.
\end{abstract}

\section{INTRODUCTION}

The length variation (heteromorphism) of the long arm of the human $Y$ chromosome is a long established fact (Denver Conference, 1960; Makino and Muramoto, 1964). Family studies indicate that $Y$ chromosome length is an inherited feature (Bishop et al., 1962; McKenzie et al., 1972). The biological and clinical significance of the heteromorphic nature of the human Y chromosome is very poorly understood. Some investigators have found a longer $Y$ in criminals (Soudek and Laraya, 1974) while others have not found any length difference between criminals and non-criminal controls (Benezich et al., 1976 and Brogger et al., 1977). Lubs and Patil (1975) suggested that there is a North/South gradient in the length of the Y in Europeans; men of Mediterranean origin having a longer Y. Further, they suggested that a long $Y$ chromosome may be an important cause of fetal loss (Patil and Lubs, 1977). In the present communication the length of $\mathrm{Y}$ chromosome was compared with each individual's height to see if a correlation existed.

Received October 3, 1981 


\section{MATERIALS AND METHODS}

The fifty normal American Blacks selected were all healthy and between the ages of 25 and 65 . The length of the $\mathrm{Y}$ chromosome was not known at the time of selection for the study. The height of each individual was recorded. All chromosome preparations were made from cultured peripheral blood (Verma et al., 1977). In order to facilitate the accurate and rapid identification of the $Y$ chromosome, QFQ cells were photographed on tri-X Pan film using a Zeiss Photomicroscope II (Verma and Lubs, 1975, 1976; Verma and Dosik, 1976). At least 20 to 30 cells were photographed from each individual with more than 1,500 cells photographed.

The five best differentiated cells were selected from each individual. Chromosomes were measured directly from the negative as there is a considerable amount of information lost during printing. Cells were projected by a Simmon Omega Point light source enlarger (Simmon Omega, Inc. NY, USA: magnification $\times 8000$ ). All chromosomes 19, 20 (F group) and the total $\mathrm{Y}$ length were measured in the same cell. The value of $F$ was based on the average lengths of chromosomes 19 and 20. From these measurements the $\mathrm{Y} / \mathrm{F}$ ratio was determined for each cell and the average was taken from five cells.

In order to determine the "functional relationship" of one variable with another (e.g. height of the individuals $v s$. total length of $\mathrm{Y}$ chromosome), a regression coefficient analysis relation was performed. A "Function" is a mathematical relation enabling us to predict what value of a variable $\mathrm{Y}(\mathrm{Y} / \mathrm{F}$ index) corresponds to given values of a variable h (height). A Y-intercept (a), and regression coefficient (b) was calculated to determine the regression equation. A test of significance of regression coefficient was also performed. We also employed correlation coefficient ( $r$ ) analysis to examine the degree to which two variables vary together. Once established, such an association is likely to lead to reasoning about causal relations between two variables. Test of significance and confidence limits for correlation coefficients were also calculated (Sokal and Rohlf, 1969).

\section{RESULTS AND DISCUSSION}

In order to examine the possible correlation between the length of the Y chromosome with the height of the individuals, we selected normal American Blacks. Because the black population has a longer $Y$ than caucasians (Verma and Dosik unpublished) perhaps more meaningful conclusions can be drawn. The average height was $172.49 \mathrm{~cm}$ and average length of the $\mathrm{Y}$ chromosome was 1.09 . A functional relation between two variables (e.g. height vs. length of the $\mathrm{Y}$ chromosome) was calculated by using regression coefficient analysis and a regression line was established (Fig. 1). The correlation coefficient (r) was also calculated and tested by the t-test. The correlation coefficient ( $r$ ) was 0.2323 and the $95 \%$ confidence interval was com- 


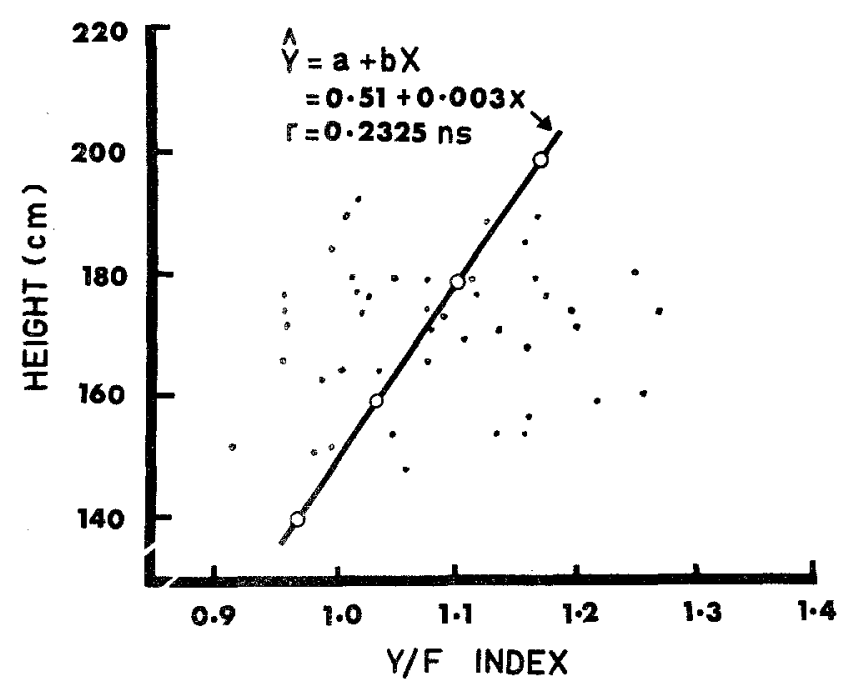

Fig. 1. The length of the $Y$ chromosome ( $Y / F$ index) is plotted against the height of the individuals. Regression line is also shown: $a$, intercept; $b$, regression coefficient and $r$, correlation coefficient which is not significant.

puted to be $0.0230-0.5573$. It was found that there was no significant correlation $(p>0.01)$ between height of an individual with length of his $Y$ chromosome. The graphic plot is shown in Fig. 1.

It is concluded from our data that the length of the $Y$ chromosome is not dependent on the height of the individuals. Thus, two variables vary independently. In man, only two genes have been assigned to the $\mathrm{Y}$ chromosome (McKusick and Ruddle, 1977). The TDF (testis determining factor) is located on the short arm, while $\mathrm{H}$-Y (Y-histocompatibility antigen) gene is located in the non-fluorescent (nf) segment of the $\mathrm{Y}$ chromosome. The present study suggests that the variable size of the $\mathrm{Y}$ chromosome does not have any phenotypic effect. The reason for the heteromorphic size of the long arm of the $\mathrm{Y}$ chromosome is still not known for certain. Extremely short $\mathrm{Y}$ chromosomes are generally thought to be the result of deletion (Conen et al., 1961; Muldal and Ockey, 1962; Nakagome et al., 1965; Genest et al., 1970). Muldal and his colleagues came to this conclusion, because of the lack of the distal portion of the $\mathrm{Y}$ chromosome.

Other clinical parameters like the size of testis, and secondary sex characteristics should be compared with the total length, fluorescent and non-fluorescent segments of the $\mathrm{Y}$ chromosome.

Acknowledgements The technical assistance of Jorge Rodriguez, Norman Schmidt and Afroza Huq is gratefully acknowledged. This research project was funded in part by the National Cancer Institute, Contract $\frac{\| N O 1-C P-43251 .}{\#}$ 


\section{REFERENCES}

Benezech, M., Noel, B., Travers, E., and Mottett, J. 1976. Conduite antisociale et longueur de chromosome Y. Hum. Genet. 32: 77-80.

Bishop, A., Blank, C.E., and Hunter, H. 1962. Heritable variation in the length of the Y chromosome. Lancet 2: 18-20.

Brogger, A., Urdal, T., Larsen, F.B., and Lavik, N.J. 1977. No evidence for a correlation between behavior and the size of the $Y$ chromosome. Clin. Genet. 11: 349-358.

Conen, P.E., Bailey, J.D., Allemang, W.H., Thompson, D.W., and Ezrin, C. 1961. A probable partial deletion of the $Y$ chromosome in an intersex patient. Lancet 2: 294-295.

Denver Conference 1960. A proposed standard system of nomenclature of human mitotic chromosomes. Lancet I: 1063-1065.

Genest, P., Laberge, C., Poty, J., Gagne, R., and Bouchard, M. 1970. Transmission d'un petit "Y" durant onze generations dans une lignee familiate. Ann. Genet. 13: 233-238.

Lubs, H.A., and Patil, S.R. 1975. Mediterranean origin of long $Y$ chromosome in caucasians. Am. J. Hum. Genet. 27: 60A.

Makino, S., and Muramoto, T. 1964. Some observations on the variability of the human $Y$ chromosome. Proc. Spn. Acad. 40: 757-761.

McKenzie, W.H., Hostetter, T.L., and Lubs, H.A. 1972. Y family study: heritable variable in the length of the human Y chromosome. Am. J. Hum. Genet. 24: 686-693.

McKusick, V.A., and Ruddle, F.H. 1977. The status of the gene map of the human chromosomes. Science 196: 390-405.

Mulda1, S., and Ockey, C.H. 1962. Deletion of Y chromosome in a family with muscular dystrophy. Brit, Med. J. 1: 291-294.

Nakagome, Y., Sasaki, M., Matsui, I., Kawazura, M., and Fukuyama, Y. 1965. A mentally retarded boy with a minute $\mathrm{Y}$ chromosome. J. Pediatrics 67: 1163-1167.

Patil, S.R., and Lubs, H.A. 1977. A possible association of long Y chromosomes and fetal loss. Hum. Genet. 35: 233-235.

Sokal, R.R., and Rohlf, F.J. 1969. Biometry: The Principles and Practices of Statistics in Biological Research (W.H. Freeman, ed.). San Francisco.

Soudek, D., and Laraya, P. 1974. Longer Y chromosome in criminals. Clin. Genet. 6: 225-229.

Verma, R.S., Rubenstein, C.T., and Dosik, H. 1977. Effect of $\mathrm{CO}_{2}$ on short term human lymphocyte culture in vitro. In Vitro 13: 806-807.

Verma, R.S., and Lubs, H.A. 1975. A simple R banding technique. Am. J. Hum. Genet. 27: 110117.

Verma, R.S., and Lubs, H.A. 1976. Additional observations on the preparation of R banded human chromosomes with acridine orange. Can. J. Genet. Cytol. 18: 45-50.

Verma, R.S., and Dosik, H. 1976. An improved method of photographing human fluorescent chromosomes. J. Microsc. 108: 339-341.

Yamada, K., Ohta, M., Yoshimura, and Hasekura, H. 1981. A possible association of Y chromosome heterochromatin with stature. Hum. Genet. 58: 268-270.

\section{ADDENDUM}

Since the preparation of this manuscript (Yamada et al.) found some correlation of height and the fluorescent portion of $\mathrm{Yq}(\mathrm{Yq} 12)$ but not a significant correlation of height with $\mathrm{Yq}$ in a Japanese population. Further measurements will have to be performed in other populations to confirm their findings. 